\title{
Analisis Nilai Tambah Usaha Pengolahan Kerupuk Rambak Di Desa Tugu Agung Kecamatan Lempuing Kabupaten OKI
}

\author{
Zainul Adhar, Imam Mashuri \\ Sekolah Tinggi Ilmu Pertanian Belitang \\ Jln.Kampus Pertanian No.3 Belitang Kab.OKU Timur Prov.Sumatera Selatan \\ e-mail: zainuladhar@gmail.com mansortok311@gmail.com
}

\begin{abstract}
ABSTRAK
Tujuan dari penelitian ini adalah untuk: 1) menghitung besarnya biaya, penerimaan dan pendapatan usaha pengolahan kulit sapi menjadi kerupuk rambak di Desa Tugu Agung Kecamatan Lempuing Kabupaten Ogan Komering Ilir, 2) menghitung besarnya nilai tambah yang diperoleh dari usaha pengolahan kulit sapi menjadi kerupuk rambak di Desa Tugu Agung Kecamatan Lempuing Kabupaten Ogan Komering Ilir, 3) menganalisis kelayakan financial usaha pengolahan pengolahan kulit sapi menjadi kerupuk rambak di Desa Tugu Agung Kecamatan Lempuing Kabupaten Ogan Komering Ilir. Hasil penelitian menunjukkan bahwa biaya yang dikeluarkan untuk usaha pengolahan kerupuk rambak maka akan menghasilkan penerimaan sebesar $\mathrm{Rp}$ 1,09 atau dari setiap Rp 1 biaya yang dikeluarkan untuk usaha pengolahan kerupuk rambak maka akan diperoleh pendapatan sebesar Rp 0,09. Karena nilai R/C > 1, ini menunjukkan bahwa usaha pengolahan kerupuk rambak di Desa Tugu Agung Kecamatan Lempuing Kabupaten OKI menguntungkan secara finansial. Nilai tambah usaha pengolahan kerupuk rambak di Desa Tugu Agung Kecamatan Lempuing Kabupaten OKI adalah sebesar Rp 864.243/Proses produksi atau diperoleh nilai tambah per Kg penjualan kerupuk rambak adalah sebesar $\mathrm{Rp}$ 21.606. Hal ini menunjukan bahwa setiap penjualan $1 \mathrm{Kg}$ kerupuk rambak akan memberikan nilai tambah sebesar Rp 21.606. Hal ini menunjukan bahwa agroindustri pengolahan kerupuk rambak di Desa Tugu Agung Kecamatan Lempuing Kabupaten OKI dapat memberikan nilai tambah secara financial bagi pelaku usaha. Berdasarkan hasil dari perhitungan nilai NPV sebesar Rp 36.393.435, nilai IRR adalah sebesar 41,8 \% dan nilai Net $\mathrm{B} / \mathrm{C}$ sebesar 1,77 .
\end{abstract}

Kata Kunci : Nilai Tambah, Kerupuk Rambak, Kelayakan Bisnis

\section{PENDAHULUAN}

\section{A. Latar Belakang}

Agroindustri merupakan suatu industri pertanian yang kegiatannya terkait dengan sektor pertanian. Keterkaitan tersebut menjadi salah satu ciri dari negara berkembang yang strukturnya mengalami transformasi dari ekonomi pertanian (agriculture) menuju industri pertanian (Agroindustri). Wujud keterkaitan ini adalah sektor pertanian sebagai industri hulu yang memasok bahan baku dan sektor industri pertanian sebagai industri yang meningkatkan nilai tambah pada hasil pertanian menjadi produk yang kompetitif (Soekartawi, 2005).

Salah satu industri pengolahan hasil pertanian yang banyak berkembang yaitu industri pengolahan pangan. Industri pengolahan pangan mempunyai prospek bisnis yang cukup baik dan keberadaannya banyak dibutuhkan masyarakat untuk mencukupi kebutuhannya terhadap pangan khususnya pangan yang berupa produk olahan, baik setengah jadi maupun sudah jadi yang siap untuk dimakan secara langsung. Pengembangan industri pengolahan pangan di Indonesia yang didukung oleh sumberdaya alam pertanian, baik nabati maupun hewani yang mampu menghasilkan berbagai produk olahan yang dapat dibuat dan dikembangkan dari sumber daya alam lokal atau daerah. Saat ini di beberapa negara Asia banyak produk pangan yang diangkat dari jenis pangan lokal dan diolah secara tradisional. Berkembangnya produk lokal tersebut maka jumlah dan jenis produk pangan menjadi semakin banyak jumlahnya (Soleh, 2003).

Sektor peternakan, sangat berkontribusi dalam hal ini, yaitu sebagai bahan baku pada industri pangan. Para peternak mencoba memanfaatkan segala sesuatu yang ada pada tubuh hewan tersebut, diantaraanya adalah kulit sapi dan kerbau. Ternak sapi dan kerbau menghasilkan produk primer olahan daging dan susu yang bisa langsung dikonsumsi, kulit dapat diolah menjadi bahan setengah jadi untuk digunakan pada industri sepatu, tas dan ikat pinggang. Kulit juga dapat diolah menjadi bahan makanan seperti kerupuk kulit, sedangkan kotorannya dapat digunakan untuk pupuk dan biogas (Rasyaf, 2008).

Dalam hal industri pangan, ternak sapi dan kerbau sebagai bahan baku kerupuk kulit sangat bernilai ekonomis. Kerupuk kulit merupakan salah satu hasil dari olahan kulit yang paling populer di masyarakat. Kerupuk kulit ini sering digunakan sebagai makanan selingan dan pelengkap makan nasi, bahkan tidak sedikit orang yang menganggap sebagai lauk-pauk setiap hari.

Kerupuk adalah bahan cemilan bertekstur kering, memiliki rasa yang enak dan renyah sehingga dapat membangkitkan selera makan serta disukai oleh semua lapisan masyarakat. Terdapat dua jenis kerupuk berdasarkan bahan bakunya, yaitu kerupuk berbahan baku pangan nabati (kerupuk singkong, kerupuk aci, kemplang), kerupuk berbahan baku tambahan pangan hewani (kerupuk udang, kerupuk ikan) dan ada pula 
kerupuk yang seutuhnya berbahan baku pangan hewani yaitu kerupuk kulit. Kerupuk biasanya dijual dalam kemasan yang belum digoreng (kerupuk mentah) atau dalam kemasan yang sudah digoreng (kerupuk matang). Sedangkan kerupuk kulit atau yang dikenal dengan kerupuk rambak adalah kerupuk yang tidak dibuat dari adonan tepung tapioka, melainkan dari kulit sapi, kerbau, kelinci, ayam atau kulit ikan yang dikeringkan (Anonymous, 2011).

Kerupuk kulit adalah produk makanan ringan yang dibuat dari kulit sapi atau kerbau melalui tahap proses pembuangan bulu, pengembangan kulit, perebusan, pengeringan, dan perendaman dengan bumbu untuk kerupuk kulit mentah atau dilanjutkan penggorengan untuk kerupuk kulit siap dikonsumsi (Standar Nasional Indonesia, 2006). Untuk memproduksi kerupuk kulit, diperlukan bahan baku kulit segar atau basah, baik yang berasal dari kulit sapi, kerbau, maupun kambing, namun kulit yang sering digunakan adalah kulit sapi dan kulit kerbau. Disamping bahan baku kulit segar banyak juga produsen yang menggunakan bahan baku kulit awet atau disebut juga kulit kering.

Salah satu jenis produk yang dikembangkan di Kecamatan Lempuing Kabupaten Ogan Komering Ilir adalah kerupuk rambak. Kerupuk rambak merupakan salah satu jenis makanan yang terbuat dari bahan baku kulit kerbau atau dari kulit sapi. Usaha pengolahan kerupuk rambak merupakan salah satu usaha untuk meningkatkan nilai tambah bagi komoditi kerbau dan sapi. Hal ini dibuktikan bahwa kerupuk rambak memiliki nilai jual yang tinggi. Hal ini merupakan suatu peluang usaha yang baik karena proses produksi kerupuk rambak relatif mudah dilakukan. Selama ini pemanfaatan utama ternak besar seperti sapi potong dan kerbau hanya terbatas pada dagingnya saja sementara untuk bagian tubuh yang lain memiliki nilai jual yang relatif rendah.

Nilai tambah merupakan penambahan nilai suatu produk sebelum dilakukan proses produksi dengan setelah dilakukan proses produksi. Pengolahan kulit sapi menjadi kerupuk rambak adalah untuk meningkatkan keawetan kulit sapi sehingga layak untuk dikonsumsi agar memperoleh nilai jual yang tinggi dipasaran. Dengan adanya kegiatan usaha pengolahan kulit sapi menjadi kerupuk rambak yang mengubah bentuk dari produk primer menjadi produk baru yang lebih tinggi nilai ekonomisnya setelah melalui proses produksi, maka akan dapat memberikan nilai tambah dan keuntungan yang lebih besar bila dibandingkan tanpa melalui proses produksi.

Salah satu agroindustri skala rumah tangga yang saat ini sedang dikembangkan di Desa Tugu Agung Kecamatan Lempuing Kabupaten Ogan Kemering Ilir adalah industri pengolahan kulit sapi sebagai bahan baku pembuatan kerupuk rambak. Pengolahan kerupuk rambak yang dilaksanakan di Desa Tugu Agung Kecamatan Lempuing memiliki prospek bisnis yang sangat cerah karena banyaknya masyarakat yang menyukai makanan ini dan harganya yang terjangkau.

Usaha pengolahan kerupuk rambak di Desa Tugu Agung Kecamatan Lempuing merupakan usaha skala rumah tangga, karena hanya dilakukan di rumah penduduk dan para pekerjanya berasal dari kalangan keluarga atau kerabat mereka sendiri. Dalam satu kali proses produksi pengolahan kerupuk rambak rata-rata membutuhkan waktu selama 7 hari dengan rata-rata jumlah kulit sapi yang dibuat sebanyak 50 sampai dengan $60 \mathrm{Kg}$. Perkembangan usaha pengolahan kerupuk rambak dapat berlangsung dengan baik karena lancarnya pemasaran kerupuk ini dan tersedianya bahan baku berupa kulit sapi segar. Adapun permasalahan yang ditemui adalah kondisi iklim dan cuaca yang tidak menentu karena pada saat proses pengeringan kulit sapi masih mengandalkan sinar matahari.

\section{B. Rumusan Masalah}

Berdasarkan latar belakang dan uraian di atas, adapun permasalahan yang menarik untuk diteliti adalah sebagai berikut :

1. Berapa besar biaya, penerimaan dan pendapatan usaha pengolahan kulit sapi menjadi kerupuk rambak di Desa Tugu Agung Kecamatan Lempuing Kabupaten Ogan Komering Ilir.

2. Berapa besar nilai tambah yang diperoleh dari usaha pengolahan kulit sapi menjadi kerupuk rambak di Desa Tugu Agung Kecamatan Lempuing Kabupaten Ogan Komering Ilir.

3. Bagaimana kelayakan financial usaha pengolahan kulit sapi menjadi kerupuk rambak di Desa Tugu Agung Kecamatan Lempuing Kabupaten Ogan Komering Ilir.

\section{Tujuan dan Kegunaan}

Berdasarkan latar belakang dan rumusan masalah di atas, maka tujuan penelitian ini adalah untuk :

1. Menghitung besarnya biaya, penerimaan dan pendapatan usaha pengolahan kulit sapi menjadi kerupuk rambak di Desa Tugu Agung Kecamatan Lempuing Kabupaten Ogan Komering Ilir.

2. Menghitung besarnya nilai tambah yang diperoleh dari usaha pengolahan kulit sapi menjadi kerupuk rambak di Desa Tugu Agung Kecamatan Lempuing Kabupaten Ogan Komering Ilir.

3. Menganalisis kelayakan financial usaha pengolahan pengolahan kulit sapi menjadi kerupuk rambak di Desa Tugu Agung Kecamatan Lempuing Kabupaten Ogan Komering Ilir.

Hasil penelitian ini diharapkan menjadi bahan informasi dan manfaat bagi pihak-pihak berkepentingan dalam meningkatkan pendapatan khususnya dalam usaha pengelolaan kulit sapi menjadi krupuk rambak di desa Tugu Agung Kecamatan Lempuing Kabupaten Ogan Komering Ilir. 


\section{KERANGKA PEMIKIRAN}

\section{A. Model Pendekatan}

Pengertian Agribisnis Menurut Sjarkowi dan Sufri (2004), Agribisnis adalah setiap usaha yang berkaitan dengan kegiatan produksi pertanian, yang meliputi pengusahaan input pertanian dan atau pengusahaan produksi itu sendiri atau pun juga pengusaha pengelolaan hasil pertanian. Agribisnis, dengan perkataan lain, adalah cara pandang ekonomi bagi usaha penyediaan pangan. Sebagai subjek akademik, agribisnis mempelajari strategi memperoleh keutungan dengan mengelola aspek budidaya, penyediaan bahan baku, pascapanen, proses pengolahan, hingga tahap pemasaran.

Kulit ternak selain sebagai bahan baku yang penting dalam industri, juga telah dimanfaatkan untuk dibuat makanan yang cukup populer yaitu rambak atau kerupuk rambak. Makanan yang berasal dari kulit ternak ini ternyata dibuat pula oleh penduduk negara tetangga yaitu Thailand dan Filipina. Di negara-negara tersebut bahan makanan yang dibuat dari kulit ini dikenal dengan nama Nung Pong atau Fried Skin (Suwarastuti 1992, diacu dalam Daniar 2008). Umumnya pengolahan hasil ternak merupakan industri rumah tangga. Rambak yang dipasarkan ada dua macam yaitu yang digunakan untuk sayur atau dicampur dalam masakan dan yang langsung dimakan berupa kerupuk.

Rambak yang dibuat dari kulit hewan, dapat berupa kulit sapi, kerbau, kambing atau babi baik yang masih segar maupun yang sudah diawetkan. Pada umumnya kulit yang dibuat rambak adalah kulit kering, meskipun kadang-kadang juga digunakan kulit segar, tetapi jumlahnya terbatas. Kebanyakan kulit segar yang baik kualitasnya diawetkan untuk bahan industri penyamakan. Kulit yang digunakan untuk krecek atau rambak adalah kulit yang sudah tidak dapat digunakan atau sisa-sisa misalnya potongan-potongan kulit bagian tepi.

Kulit kerbau atau kulit sapi yang umumnya digunakan sebagai bahan baku kerupuk rambak kulit. Kulit direbus sekitar 15 menit hingga bulu dan kulit luar mudah dikelupas. Kulit dikerok dengan menggunakan pisau sampai bersih, dipotong-potong segi empat kurang lebih $10 \mathrm{~cm}$, lalu direbus kembali sampai matang. Proses selanjutnya adalah pendinginan dan pembersihan serta pengambilan daging yang masih melekat di kulit. Kulit dipotong kecil-kecil sekitar $2 \mathrm{~cm}$, dijemur kurang lebih 2-3 hari. Apabila kulit tidak dijemur sampai kering dapat membuat kerupuk hancur pada saat penggorengan. Proses terakhir adalah proses penggorengan dan pemberian bumbu. Proses inilah yang paling sulit, karena penggorengan akan menentukan kerupuk yang mengembang dan renyah sedangkan pemberian bumbu (bawang putih dan garam) akan menentukan merata atau tidaknya bumbu.

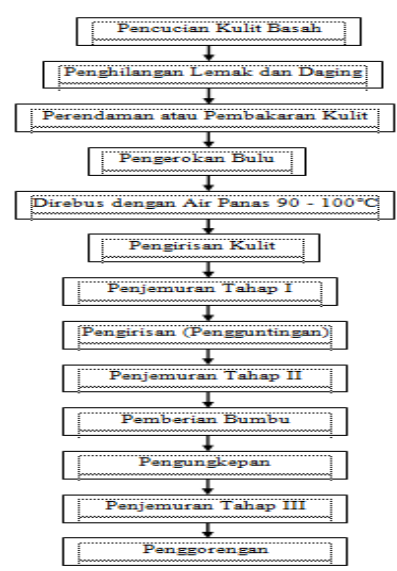

Gambar 1. Diagram Alir Pembuatan Kerupuk Rambak

Arahan konseptual dan asumsi-asumsi yang terkandung dalam uraian di atas memungkinkan tersususunnya suatu kerangka berfikir argumentatif berupa model pendekatan, bagan alir pada gambar berikut :

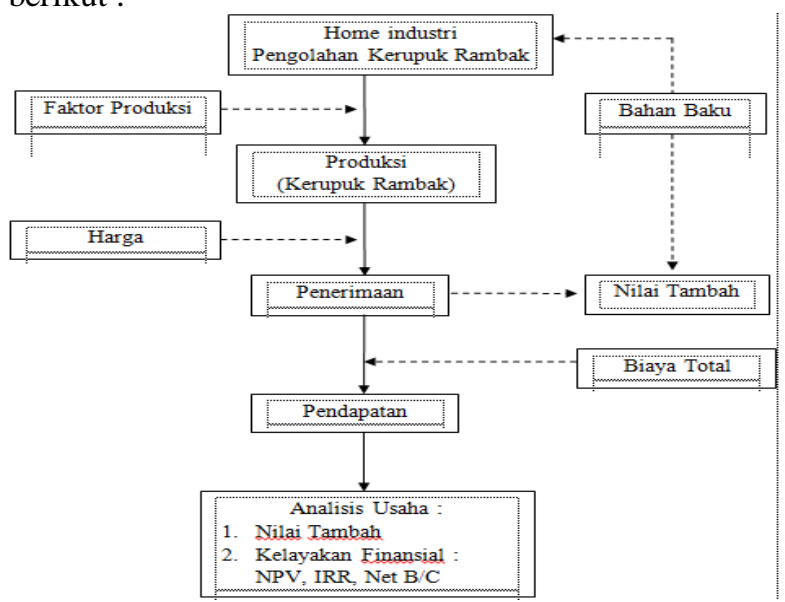

Keterangan :

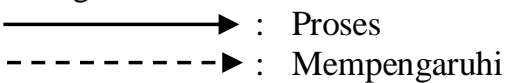

Gambar 2. Model Pendekatan Diagramatis Usaha Pengolahan Krupuk Rambak.

Model pendekatan secara matematis adalah sebagai berikut :

1). Untuk mengetahui biaya produksi dengan rumus (Suratiyah, 2006) :

$\mathrm{TC}=\mathrm{FC}+\mathrm{VC}$

$\mathrm{TC}=$ Total Cost (Biaya Produksi)

$\mathrm{FC}=$ Fixed Cost (Biaya Tetap)

$\mathrm{VC}=$ Variable Cost (Biaya Variabel $)$

2). Untuk mengetahui penerimaan, digunakan rumus (Suratiyah, 2006) :

$\mathrm{TR}=\mathrm{Y} \times \mathrm{P}$

$\mathrm{TR}=$ Total Revenues $/$ Penerimaan

$\mathrm{Y}=$ Yield/Hasil Produksi

$\mathrm{P}=$ Price/Harga Jual

3). Untuk menghitung pendapatan, digunakan rumus (Suratiyah, 2006) :

$\mathrm{I}=\mathrm{TR}-\mathrm{TC}$

$\mathrm{I}=$ Income/Pendapatan

$\mathrm{TR}=$ Total Revenue $/$ Penerimaan 
$\mathrm{TC}=$ Total Cost $/$ Total Biaya Produksi

4). Untuk menghitung nilai tambah digunakan rumus (Ariadi dan Relawati, 2011):

$\mathrm{NT}=\mathrm{TR}-\mathrm{IC}$

Dimana :

$\mathrm{NT}=$ Nilai Tambah $(\mathrm{Rp} / \mathrm{Kg})$

$\mathrm{TR}=$ Total Revenue $(\mathrm{Rp} / \mathrm{Kg})$

$\mathrm{IC}=$ Intermediate Cost/Biaya antara $(\mathrm{Rp} / \mathrm{Kg})$

$\mathrm{IC}=$ (Biaya Produksi - Biaya tenaga kerja)

5). Untuk menghitung NPV maka digunakan rumus (Ibrahim, 2009) :

$\mathrm{NPV}=\Sigma \mathrm{N} \overline{\mathrm{B}}$

Dimana :

NPV = Net Present Value / Nilai Kini Bersih

$\mathrm{NB}=$ Net Benefit yang telah didiscount factor

Dengan kriteria :

NPV > 0 : maka usaha layak (feasible)

$\mathrm{NPV}<0$ : maka usaha tidak layak untuk dilaksanakan

NPV $=0:$ maka usaha dalam keadaan impas

6). Untuk menghitung Internal Rate Ratio (IRR) digunakan rumus (Ibrahim, 2009)

$I R R=i_{1}+\frac{N P V_{1}}{\left(N P V_{1}-N P V_{2}\right)} \times\left(i_{2}-i_{1}\right)$.

Dimana :

$\mathrm{NPV}_{1}=\mathrm{NPV}$ pada tingkat discount rate tertinggi (positif).

$\mathrm{NPV}_{2}=\mathrm{NPV}$ pada tingkat discount rate terendah (negative).

$\mathrm{i}_{1}=$ Discount rate tertinggi

$\mathrm{i}_{2}=$ Discount rate terendah

Dengan kriteria :

IRR > SOCC : maka usaha layak (feasible)

IRR < SOCC : maka usaha tidak layak

7). Untuk menghitung nilai net $\mathrm{B} / \mathrm{C}$ ratio maka digunakan rumıc (Thrahim 2009) :

$$
\mathrm{NetB} / \mathrm{C}=\frac{\sum \mathrm{NB}(+)}{\sum \mathrm{NB}(-)}
$$

Dimana :

$\Sigma \mathrm{NB}(+)=$ Net Benefit yang telah didiscount positif.

$\Sigma$ NB (-) = Net Benefit yang telah didiscount negative.

Dengan kriteria :

Net B/C > 0 Berarti usaha layak dikembangkan

Net $B / C=0$ Berarti usahatani tidak untung dan tidak rugi (impas)

Net B/C $<0$ Berarti usaha tidak layak

\section{B. Hipotesis}

Berdasarkan latar belakang, kerangka pemikiran dan uraian di atas maka hipotesis yang diajukan dalam penelitian ini adalah :

1. Diduga bahwa penerimaan yang diterima lebih besar dari pada biaya produksi sehingga diperoleh pendapatan pada usaha pengolahan kulit sapi menjadi kerupuk rambak di Desa Tugu Agung Kecamatan Lempuing Kabupaten Ogan Komering Ilir.
2. Diduga bahwa pengolahan kulit sapi menjadi kerupuk rambak di Desa Tugu Agung Kecamatan Lempuing Kabupaten Ogan Komering Ilir dapat memberikan nilai tambah secara finansial.

3. Diduga bahwa usaha pengolahan kulit sapi menjadi kerupuk rambak di Desa Tugu Agung Kecamatan Lempuing Kabupaten Ogan Komering Ilir layak secara finansial.

\section{Batasan-Batasan}

Batasan yang akan digunakan dalam penelitian ini adalah sebagai berikut :

1. Responden adalah adalah industri skala rumah tangga yang melakukan usaha pengolahan kulit sapi menjadi kerupuk rambak di Desa Tugu Agung Kecamatan Lempuing Kabupaten OKI.

2. Kerupuk rambak adalah kerupuk yang dibuat dari kulit sapi yang telah melalui beberapa tahapan proses sampai dengan penggorengan sehingga kerupuk kulit siap untuk dikonsumsi.

3. Industri rumah tangga yaitu industri yang menggunakan tenaga kerja kurang dari empat orang. Ciri industri ini memiliki modal yang sangat terbatas, tenaga kerja berasal dari anggota keluarga, dan pemilik atau pengelola industri biasanya kepala rumah tangga itu sendiri.

4. Agroindustri adalah industri yang bergerak di bidang pertanian, baik itu pengolahan hasil pertanian, penyedia bahan baku, maupun industri pendukung pertanian lainnya.

5. Produksi adalah banyaknya kerupuk rambak yang dihasilkan dalam satu kali proses produksi (Kg/Proses).

6. Proses produksi adalah waktu yang dibutuhkan dalam mengolah kulit sapi mentah menjadi kerupuk rambak yaitu rata-rata selama 7 hari.

7. Harga adalah harga jual kerupuk rambak pada saat penelitian ( $\mathrm{Rp} / \mathrm{Kg})$.

8. Biaya tetap adalah biaya yang besarnya tidak dipengaruhi oleh jumlah produksi dan tidak habis dalam satu kali proses produksi, meliputi biaya penyusutan peralatan dan biaya sewa tempat (Rp/Proses).

9. Biaya variabel adalah biaya yang dipengaruhi besar kecilnya produksi dan habis dalam satu kali proses, meliputi biaya bahan baku dan tenaga kerja (Rp/Proses).

10. Biaya total adalah semua biaya yang digunakan dalam usaha pembuatan kerupuk rambak, meliputi biaya tetap ditambah biaya variabel (Rp/Proses).

11. Penerimaan usaha adalah perkalian antara produksi kerupuk rambak yang terjual dengan harga jual kerupuk rambak (Rp/Proses).

12. Pendapatan adalah selisih antara total penerimaan dengan biaya total usaha pengolahan kerupuk rambak (Rp/Proses).

13. Biaya antara (Intermediate Cost) adalah biaya yang digunakan dalam proses pengolahan bawang merah menjadi kerupuk rambak selain biaya tenaga kerja (Biaya produki - Biaya tenaga kerja) 
14. Nilai tambah adalah selisih antara nilai output (penerimaan) dengan nilai biaya antara (Intermediate Cost) dengan satuan $(\mathrm{Rp} / \mathrm{Kg})$.

15. Net Present Value (NPV) adalah nilai sekarang dari keuntungan bersih (manfaat netto tambahan) yang akan diperoleh pada masa mendatang.

16. Internal Rate of Return (IRR) digunakan untuk mencari tingkat bunga yang menyamakan nilai sekarang dari arus kas yang diharapkan di masa datang, atau penerimaan kas, dengan mengeluarkan investasi awal.

17. Net Benefit Cost (Net B/C) adalah perbandingan antara present value yang dari net benefit yang positif dengan present value dari net benefit yang negatif.

\section{PELAKSANAAN PENELITIAN}

\section{A. Tempat dan Waktu}

Penelitian ini akan dilaksanakan di Desa Tugu Agung Kecamatan Lempuing Kabupaten Ogan Komering Ilir. Pemilihan lokasi dilakukan secara sengaja (purposive) dengan pertimbangan bahwa di desa tersebut terdapat industri skala rumah tangga yang mengolah kulit sapi menjadi kerupuk rambak. Penelitian akan dilaksanakan pada Bulan Juli 2020.

\section{B. Metode Penelitian dan Penarikan Contoh}

Metode penelitian yang akan digunakan dalam penelitian ini adalah metode studi kasus (case study). Menurut Nazir (2005), studi kasus adalah penelitian tentang kasus subyek penelitian yang berkenaan dengan suatu fase spesifik atau khas dari keseluruhan personalitas. Tujuan studi kasus adalah untuk memberikan gambaran secara detail tentang latar belakang, sifat-sifat serta karakter-karakter yang khas dari kasus atau pun status individu yang kemudian dari sifat-sifat tersebut akan dijadikan suatu hal yang bersifat umum.

Adapun metode penarikan contoh yang digunakan dalam penelitian ini adalah metode sensus yaitu, suatu metode dimana setiap elemen populasinya dijadikan sebagai anggota sampel. Dalam penelitian ini sampel berjumlah 1 responden dari 1 populasi industri skala rumah tangga yang melakukan usaha pengolahan kulit sapi menjadi kerupuk rambak di Desa Tugu Agung Kecamatan Lempuing Kabupaten Ogan Komering Ilir.

\section{Metode Pengumpulan Data}

Sumber dan jenis data yang digunakan dalam penelitian ini terdiri dari data primer dan data sekunder. Data primer adalah merupakan data yang diperoleh secara langsung pelaku usaha berupa hasil pengamatan serta wawancara dan observasi. Data sekunder adalah merupakan data yang tidak langsung yang diperoleh dari dokumen-dokumen. Dalam hal ini bersumber dari penelitian yang meliputi buku- buku bacaan, hasil penelitian ilmiah dan literatur lainnya yang berkaitan dengan penelitian.

\section{Metode Pengolahan Data}

Data yang diperoleh dari lapangan diolah secara tabulasi lalu dianalisis secara deskriptif yaitu metode penelitian dengan menggunakan angka-angka yang kemudian diolah, dianalisis, dijabarkan dan ditarik kesimpulan.

1. Untuk menjawab tujuan penelitian yang pertama yaitu untuk mengetahui besarnya biaya, penerimaan dan pendapatan usaha pengolahan kulit sapi menjadi kerupuk rambak di Desa Tugu Agung Kecamatan Lempuing Kabupaten Ogan Komering Ilir maka dihitung dengan menggunakan rumus :

1). Untuk menghitung biaya produksi digunakan rumus (Soekartawi, 2002) :

$\mathrm{TC}=\mathrm{FC}+\mathrm{VC}$

$\mathrm{TC}=$ Total Cost/Total Biaya Produksi (Rp/Proses)

$\mathrm{FC}=$ Fixed Cost/Biaya Tetap (Rp/Proses)

$\mathrm{VC}=$ Variable Cost/Biaya Variabel (Rp/Proses)

2). Untuk menghitung penerimaan, digunakan rumus (Soekartawi, 2002):

$\mathrm{TR}=\mathrm{Py} \times \mathrm{Y}$

$\mathrm{TR}=$ Total Revenues $/$ Penerimaan $(\mathrm{Rp} /$ Proses $)$

$\mathrm{Py}=$ Price Yield/Harga Jual Produk $(\mathrm{Rp} / \mathrm{Kg})$

$\mathrm{Y}=$ Yield $/$ Hasil produksi (Kg/Proses)

3). Untuk menghitung pendapatan, digunakan rumus (Suratiyah, 2006) :

$\mathrm{I}=\mathrm{TR}-\mathrm{TC}$

$\mathrm{I}=$ Income/Pendapatan $(\mathrm{Rp} /$ Proses $)$

$\mathrm{TR}=$ Total Revenue $/$ Penerimaan (Rp/Proses)

$\mathrm{TC}=$ Total Cost/Total Biaya Produksi (RpProses)

2. Untuk menjawab tujuan penelitian yang kedua yaitu untuk menganalisis nilai tambah usaha pengolahan kulit sapi menjadi kerupuk rambak di Desa Tugu Agung Kecamatan Lempuing Kabupaten Ogan Komering Ilir maka dihitung dengan menggunakan rumus berikut :

4). Untuk menghitung nilai tambah digunakan rumus (Yudi, 2010) :

$\mathrm{NT}=\mathrm{TR}-\mathrm{IC}$

Keterangan :

$\mathrm{NT}=$ Nilai Tambah $(\mathrm{Rp} / \mathrm{Kg})$

$\mathrm{TR}=$ Total Revenue/Total Penerimaan (Rp/Proses)

$\mathrm{IC}=$ Intermediate Cost/Biaya antara (Rp/Proses)

3. Untuk menjawab tujuan penelitian yang ketiga yaitu untuk menganalisis kelayakan finansial usaha pengolahan kulit sapi menjadi kerupuk rambak di Desa Tugu Agung Kecamatan Lempuing Kabupaten Ogan Komering Ilir dihitung dengan menggunakan rumus NPV, IRR dan Net B/C :

5). Untuk menghitung NPV maka digunakan rumus (Ibrahim, 2009) :

$\mathrm{NPV}=\Sigma \mathrm{NB}$

Keterangan :

NPV $=$ Net Present Value / Nilai Kini Bersih

$\mathrm{N} \overline{\mathrm{B}}=$ Net Benefit yang telah didiscount factor

Dengan kriteria :

NPV > 0 maka usaha layak (feasible) 
NPV < 0 maka usaha tidak layak untuk dilaksanakan

$\mathrm{NPV}=0$ maka usaha dalam keadaan impas

6). Untuk menghitung Internal Rate of Return (IRR) maka digunakan rumus : (Ibrahim, 2009).

$I R R=i_{1}+\frac{N P V_{1}}{\left(N P V_{1}-N P V_{2}\right)} \times\left(i_{2}-i_{1}\right)$

Dimana :

$\mathrm{NPV}_{1}=$ Net Present Value yang bernilai positif terkecil.

$\mathrm{NPV}_{2}=$ Net Present Value yang bernilai negatif terkecil.

$\mathrm{i}_{1}=$ Discount rate yang menghasilkan NPV positif terkecil.

$\mathrm{i}_{2}=$ Discount rate yang menghasilkan NPV negatif terkecil.

SOCC = Social Opportunity Cost of Capital (Tingkat Bunga Berlaku Kini)

Dengan kriteria :

IRR > SOCC : maka usaha layak

IRR < SOCC : maka usaha tidak layak

7). Untuk menghitung nilai net $\mathrm{B} / \mathrm{C}$ maka digunakan rumus (Ibrahim, 2009) :

$$
\text { Net B/C }=\frac{\sum \mathrm{NB}(+)}{\sum \mathrm{NB}(-)}
$$

Dimana :

$\Sigma \mathrm{NB}(+)=$ Net Benefit yang telah didiscount positif

$\Sigma$ NB (-) = Net Benefit yang telah didiscount negatif

Dengan kriteria :

Net $\mathrm{B} / \mathrm{C}>1$ Berarti usaha layak dikembangkan

Net $\mathrm{B} / \mathrm{C}=1$ Berarti usaha tidak untung dan tidak rugi (impas)

Net B/C $<1$ Berarti usaha tidak layak

\section{HASIL DAN PEMBAHASAN}

\section{A. Analisis Usaha Pengolahan Kerupuk Rambak 1. Biaya Tetap (Fixed Cost)}

Biaya tetap yang digunakan dalam usaha pengolahan kerupuk rambak di antaranya meliputi biaya sewa lahan dan biaya penyusutan peralatan yang dapat dilihat pada tabel 1 sebagai berikut :

Tabel 1. Biaya Tetap Usaha Pengolahan Kerupuk Rambak di Desa Tugu Agung Kecamatan Lempuing Kabupaten OKI.

\begin{tabular}{clr}
\hline No & Komponen Biaya & Nilai (Rp/Proses) \\
\hline 1. & Sewa Tempat Usaha & $\mathbf{4 6 . 6 6 7}$ \\
2. & Penyusutan Alat & $\mathbf{4 4 . 3 4 1}$ \\
& a. Kuali Besar & 7.346 \\
& b. Kuali Kecil & 1.836 \\
& c. Wajan Besar & 3.261 \\
& d. Timbangan Digital & 3.061 \\
e. Kompor gas & 3.442 \\
f. Tabung Gas & - \\
g. Sealer & 3.261 \\
h. Rak Bambu & 1.458 \\
i. Meja Panjang & 3.111 \\
j. Serok Besar & 3.665 \\
k. Serok Kecil & 2.917 \\
1. Baskom Plastik & 1.944 \\
m. Baskom Seng & 972 \\
n. Sutil & 1.750 \\
o. Tikar & 3.889 \\
& p. Mangkok Seng & 972 \\
q. Sendok Pengaduk & 1.556 \\
\hline Biaya Tetap & $\mathbf{9 1 . 0 0 7}$ \\
\hline
\end{tabular}

Sumber : Data Olahan Primer, 2020.
Biaya sewa tempat usaha pengolahan kerupuk rambak di Desa Tugu Agung Kecamatan Lempuing Kabupaten OKI dalam satu kali proses produksi (7 hari) rata-rata adalah sebesar $\mathrm{Rp} 46.667$ atau rata-rata sebesar Rp 200.000/Bulan. Adapun rata-rata biaya penyusutan peralatan pengolahan kerupuk rambak dalam satu kali proses produksi adalah sebesar Rp 44.341 atau rata-rata sebesar Rp 190.032/Bulan. Adapun besarnya biaya tetap usaha pengolahan kerupuk rambak di Desa Tugu Agung Kecamatan Lempuing Kabupaten OKI yang terdiri dari biaya sewa lahan dan biaya penyusutan peralatan dalam satu kali proses produksi rata-rata adalah sebesar Rp 99.007 atau rata-rata sebesar Rp 390.092/Bulan.

\section{Biaya Variabel (Variable Cost)}

Biaya variabel terdiri atas biaya pembelian bahan baku dan biaya tenaga kerja. Biaya bahan baku pengolahan kerupuk rambak digunakan untuk pembelian kulit sapi kering, minyak goreng, plastik kemasan, gas elpiji, label, pnyedap rasa dan listrik.

Tabel 2. Biaya Variabel Usaha Pengolahan Kerupuk Rambak di Desa Tugu Agung Kecamatan Lempuing Kabupaten OKI.

\begin{tabular}{clr}
\hline No & Komponen Biaya & Nilai (Rp/ Proses) \\
\hline 1. & Biaya Bahan Baku & $\mathbf{4 . 7 9 4 . 2 5 0}$ \\
& a. Kulit Sapi Kering & 4.000 .000 \\
& b. Minyak Goreng & 360.000 \\
& c. Plastik Besar & 25.000 \\
& d. Plastik $0,5 \mathrm{Kg}$ & 21.250 \\
& e. Plastik $0,25 \mathrm{Kg}$ & 27.000 \\
& f. Plastik $0,1 \mathrm{Kg}$ & 45.500 \\
& g. Gas Elpiji & 96.000 \\
& h. Label & 150.000 \\
& i. Penyedap rasa & 20.000 \\
& j. Biaya Listrik & 10.000 \\
2. & Biaya Tenaga Kerja & $\mathbf{4 0 0 . 0 0 0}$ \\
3. & Biaya Variabel & $\mathbf{5 . 1 9 4 . 7 5 0}$ \\
\hline
\end{tabular}

Sumber : Data Olahan Primer, 2020.

Besarnya biaya pembelian bahan baku diantaranya untuk pembelian kulit sapi kering, minyak goreng, plastik kemasan, penyedap rasa, label, gas elpiji dan listrik dalam satu kali proses produksi ratarata adalah sebesar $\mathrm{Rp}$ 4.794.250 atau rata-rata sebesar Rp 20.548.929/Bulan. Besarnya biaya tenaga kerja dalam satu kali proses produksi rata-rata adalah sebesar $\mathrm{Rp} \quad 400.000$ atau sebesar Rp 1.714.286/Bulan. Besarnya biaya variabel usaha pengolahan kerupuk rambak di Desa Tugu Agung Kecamatan Lempuing Kabupaten OKI yang terdiri dari biaya bahan baku dan biaya tenaga kerja dalam satu kali proses produksi adalah sebesar Rp 5.194.750 atau rata-rata sebesar Rp 22.263.214/Bulan.

\section{Biaya Total (Total Cost)}

Biaya total dalam usaha pengolahan kerupuk rambak terdiri dari biaya tetap ditambah dengan biaya variabel.

Tabel 3. Biaya Total Usaha Pengolahan Kerupuk Rambak di Desa Tugu Agung Kecamatan Lempuing Kabupaten OKI. 


\begin{tabular}{clr}
\hline No Komponen Biaya & Nilai (Rp Proses) \\
\hline 1. & Biaya Tetap & 91.007 \\
& a. Sewa Tempat & 46.667 \\
& b. Penyusutan Peralatan & 44.341 \\
2. Biaya Variabel & $\mathbf{5 . 1 9 4 . 7 5 0}$ \\
a Biaya Bahan Baku & 4.794 .750 \\
b. Biaya Teraga Kerja & 400.000 \\
\hline 3. & Total Biay a Produksi & $\mathbf{5 . 2 8 5 . 7 5 7}$
\end{tabular}

Sumber : Data Olahan Primer, 2020.

Berdasarkan hasil pada tabel 3, dapat diketahui bahwa biaya tetap usaha pengolahan kerupuk rambak yang terdiri dari biaya sewa tempat dan biaya penyusutan peralatan dalam satu kali proses produksi adalah sebesar Rp 91.007 atau sebesar Rp 390.032/Bulan. Biaya variabel yang terdiri dari biaya bahan baku dan biaya tenaga kerja dalam satu kali proses produksi adalah rata-rata adalah sebesar $\mathrm{Rp}$ 5.194.750 atau sebesar Rp 22.263.214/Bulan, sehingga diperoleh biaya total produksi usaha pengolahan kerupuk rambak di Desa Tugu Agung Kecamatan Lempuing Kabupaten OKI yang terdiri biaya tetap dan biaya variabel dalam satu kali proses produksi rata-rata adalah sebesar Rp 5.285.757 atau rata-rata sebesar Rp 22.653.246/Bulan.

4.Produksi, Harga, Penerimaan dan Pendapatan

Hasil akhir atau produksi dalam usaha pengolahan kerupuk rambak adalah berupa kerupuk rambak yang siap untuk dikonsumsi. Produksi adalah kerupuk rambak yang dihasilkan selama satu kali proses produksi dan diukur dalam satuan kilogram. Satu kali proses proses membutuhkan waktu rata-rata selama 7 (tujuh) hari. Kerupuk rambak yang diproduksi oleh responden terdiri dari 3 kemasan yaitu kemasan 10 gram dengan harga jual rata-rata Rp 1.500/Bks, kemasan 30 gram dengan harga jual rata-rata $\mathrm{Rp}$ 4.000/Bks dan kemasan 60 gram dengan harga jual rata-rata $\mathrm{Rp}$ 8.000/Bks.

Tabel 4. Analisis Usaha Pengolahan Kerupuk Rambak di Desa Tugu Agung Kecamatan Lempuing Kabupaten OKI.

\begin{tabular}{|c|c|c|c|}
\hline Wo & Traizn & Satuan & T:il: $\mathrm{i}$ \\
\hline \multirow[t]{4}{*}{1} & Promentei & & \\
\hline & a Kemasm $10 \mathrm{Gram}$ & Eunghous Froses: & 1300 \\
\hline & 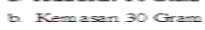 & Funghus Froses: & 450 \\
\hline & a Kemasan $60 \mathrm{Gram}$ & Founghas Froses: & 250 \\
\hline \multirow[t]{4}{*}{2} & Fer & & \\
\hline & a Komasan $10 \mathrm{Gm}$ & Fup Esurgahos: & 1500 \\
\hline & be Fendasen 30 Gram & Fpp Furnahes & 4000 \\
\hline & 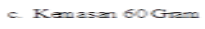 & Rep Dourgathes & as 000 \\
\hline \multirow[t]{4}{*}{3} & Penerinazan & & \\
\hline & 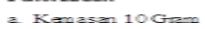 & Dep Foses & 1050000 \\
\hline & We Kemiasen 30 Grind & Epilporses & $1 \$ 000000$ \\
\hline & $=$ Kemasm $60 \mathrm{Gmm}$ & Rpp Ftoses & 20000000 \\
\hline 4 & Iotal Fenerimaan & Flpi Froses & 5.60750000 \\
\hline$x$ & Biays Froctulibsi & Flpi Forses & 52855757 \\
\hline$=$ & Fondeputan & 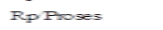 & 464243 \\
\hline 7 & FuC Rlasio & & $1, \infty$ \\
\hline
\end{tabular}

Sumber : Data Olahan Primer, 2020.

Rata-rata produksi kerupuk rambak yang dihasilkan dalam satu kali proses produksi untuk kemasan 10 gram rata-rata adalah sebanyak 1.300 bungkus dengan nilai jual sebesar Rp 1.950.000, kemasan 30 gram rata-rata sebanyak 450 bungkus dengan nilai jual sebesar Rp 1.800 .000 dan kemasan 60 gram rata-rata sebanyak 250 bungkus dengan nilai jual sebesar Rp 2.000.000 sehingga diperoleh total penerimaan dalam satu kali proses produksi rata-rata sebesar Rp 5.750.000. Pendapatan usaha merupakan hasil dari penerimaan dikurangi dengan biaya produksi. Rata-rata total biaya produksi usaha pengolahan kerupuk rambak dalam satu kali proses adalah sebesar Rp 5.285.757. Rata-rata penerimaan usaha pengolahan kerupuk rambak adalah sebesar Rp 5.750.000/Proses sehingga pendapatan usaha pengolahan kerupuk rambak di Desa Tugu Agung Kecamatan Lempuing Kabupaten OKI dalam satu kali proses produksi ratarata adalah sebesar $\mathrm{Rp}$ 464.243.

$\mathrm{R} / \mathrm{C}$ rasio usaha pengolahan kerupuk rambak adalah sebesar 1,09. Nilai R/C rasio sebesar 1,09 artinya bahwa setiap satu rupiah biaya yang dikeluarkan untuk usaha pengolahan kerupuk rambak maka akan menghasilkan penerimaan sebesar Rp 1,09 atau dari setiap Rp 1 biaya yang dikeluarkan untuk usaha pengolahan kerupuk rambak maka akan diperoleh pendapatan sebesar $\mathrm{Rp}$ 0,09. Karena nilai $\mathrm{R} / \mathrm{C}>1$, ini menunjukkan bahwa usaha pengolahan kerupuk rambak di Desa Tugu Agung Kecamatan Lempuing Kabupaten OKI menguntungkan secara finansial.

\section{B. Analisis Nilai Tambah}

Proses pengolahan kulit sapi kering menjadi kerupuk rambak akan memberikan nilai tambah bagi kulit sapi itu sendiri. Sedangkan untuk menghasilkan produk berupa kerupuk rambak tersebut diperlukan faktor-faktor produksi lain mulai dari tenaga kerja, peralatan produksi, bahan-bahan tambahan dan lainlain.

Nilai akhir atau penerimaan diperoleh dari produksi kerupuk rambak yaitu rata-rata sebanyak 41,5 $\mathrm{Kg} /$ proses dikali dengan harga jual kerupuk rambak yaitu rata-rata $\mathrm{Rp} 143.700 / \mathrm{Kg}$ sehingga diperoleh nilai akhir kerupuk rambak adalah sebesar Rp 5.750.000/Proses. Biaya tenaga kerja diperoleh dari pembayaran upah tenaga kerja yaitu sebesar Rp 400.000/proses. Biaya antara atau Intermediate Cost (IC) diperoleh dari total biaya produksi yaitu sebesar Rp 5.285.757/Proses dikurangi dengan biaya tenaga kerja yaitu sebesar Rp 400.000/Proses sehingga diperoleh nilai rata-rata biaya antara (IC) adalah sebesar Rp 4.887.757/Proses.

Tabel 5. Nilai Tambah Pengolahan Kerupuk Rambak di Desa Tugu Agung Kecamatan Lempuing Kabupaten OKI.

\begin{tabular}{rllr} 
No & Uraian & Satuan & \multicolumn{1}{l}{ Nilai } \\
\hline 1. & Kebutuhan Kulit Sapi Kering & Kg/Proses & 50 \\
2. & Rata-rata Produksi Kerupuk Rambak & Kg/Proses & 41.5 \\
3. & Rata-rata Harga Jual Kerupuk Rambak & Rp/Kg & 143.750 \\
4. & Nilai Akhir Kerupuk Rambak & Rp/Proses & 5.750 .000 \\
5. & Total Biaya Produksi & Rp/Proses & 5.285 .757 \\
6. & Biaya Tenaga Kerja & Rp/Proses & 400.000 \\
7. & Biaya Antara (Intermediate Cost) & Rp/Proses & 4.887 .757 \\
8. & Nilai Tambah & Rp/Proses & 864.243 \\
9. & Nilai Tambah (Per KgRam bak) & Rp/Kg & 21.606
\end{tabular}

Sumber : Data Olahan Primer, 2020.

Nilai tambah diperoleh dari total penerimaan atau nilai akhir kerupuk rambak sebesar 5.750.000/Proses dikurangi dengan nilai biaya antara 
yaitu sebesar Rp 4.887.757/Proses sehingga diperoleh nilai tambah usaha pengolahan kerupuk rambak di Desa Tugu Agung Kecamatan Lempuing Kabupaten OKI adalah sebesar Rp 864.243/Proses produksi atau diperoleh nilai tambah per $\mathrm{Kg}$ penjualan kerupuk rambak adalah sebesar Rp 21.606. Hal ini menunjukan bahwa setiap penjualan $1 \mathrm{Kg}$ kerupuk rambak akan memberikan nilai tambah sebesar Rp 21.606. Hal ini menunjukan bahwa agroindustri pengolahan kerupuk rambak di Desa Tugu Agung Kecamatan Lempuing Kabupaten OKI dapat memberikan nilai tambah secara financial bagi pelaku usaha.

\section{Analisis Kelayakan Aspek Finansial}

Dalam penelitian ini analisis kelayakan usaha dihitung selama 4 tahun usaha pengolahan kerupuk rambak berjalan yaitu dimulai dari tahun 2017 sampai dengan tahun 2020. Perhitungan analisis kelayakan usaha menggunakan perhitungan mundur ke belakang atau dengan Compounding Factor (CF) dengan tingkat suku bunga $12 \%$ per tahun

\section{Analisis NPV}

Net Present Value (NPV) atau nilai sekarang bersih adalah analisis manfaat finansial yang digunakan untuk mengukur layak tidaknya suatu usaha dilaksanakan dilihat dari nilai sekarang (present value). Kriteria kelayakan dari usaha ini adalah : proyek layak jika NPV lebih besar dari nol (positif) dan sebaliknya proyek tidak layak jika NPV nilainya lebih kecil dari nol (negatif).

Tabel 6. Analisis NPV Usaha Pengolahan Kerupuk Rambak di Desa Tugu Agung Kecamatan Lempuing Kabupaten OKI.

\begin{tabular}{|c|c|c|c|c|c|c|}
\hline Tahum & Tahum Ke & Total Cost & Penermaan & Pendapatan & \multicolumn{2}{|c|}{ CF $12 \%$ Present Vahe $18 \%$} \\
\hline 2017 & 3 & 231.373 .233 & 198.000 .000 & $(33.373 .233)$ & 1,4049 & $(46.886 .990)$ \\
\hline 2018 & 2 & 219.855 .483 & 247.212 .000 & 27.356 .517 & 1,2544 & 34.316 .015 \\
\hline 2019 & 1 & 243.768 .343 & 277.477 .000 & 33.708 .657 & 1,1200 & 37.753 .696 \\
\hline 2020 & 0 & 136.599 .286 & 147.810 .000 & 11.210 .714 & 1,0000 & 11.210 .714 \\
\hline & & 831.596 .345 & 870.499 .000 & 38.902 .655 & NPV & 36.393 .435 \\
\hline
\end{tabular}

Sumber : Data Olahan Primer, 2020.

Hasil analisis pada tabel diatas diperoleh nilai investasi usaha pengolahan kerupuk rambak selama 4 tahun adalah sebesar Rp 62.480.000. Biaya operasional selama 4 tahun adalah sebesar Rp 769.116.345 sehingga diperoleh biaya total sebesar Rp 831.596.345. Total penerimaan usaha pengolahan kerupuk rambak selama 4 tahun adalah sebesar Rp 870.499.000 sehingga diperoleh total pendapatan usaha selama 4 tahun adalah sebesar Rp. 38.902.656.

Dari perhitungan NPV selama 4 tahun usaha yaitu dari tahun 2017 sampai tahun 2020 dengan menggunakan Compounding Faktor dengan tingkat suku bunga acuan sebesar $12 \%$ maka diperoleh nilai NPV usaha pengolahan kerupuk rambak adalah sebesar Rp 36.393.435. Berdasarkan analisis diperoleh bahwa nilai NPV > 0, Hal ini menunjukan bahwa usaha pengolahan kerupuk rambak di Desa Tugu Agung Kecamatan Lempuing Kabupaten OKI layak secara financial untuk diteruskan.

\section{Analisis IRR (Internal Rate of Return)}

IRR menunjukkan kemampuan suatu investasi atau usaha dalam menghasilkan return atau tingkat keuntungan yang bisa dipakai. Kriteria yang dipakai untuk menunjukkan bahwa suatu usaha layak dijalankan adalah jika nilai IRR lebih besar dari tingkat suku bunga yang berlaku pada saat usaha tersebut diusahakan (Gittinger, 2009). Jadi, jika IRR lebih tinggi dari tingkat bunga bank atau lebih tinggi dari Social Oportunity Cost of Capital (SOCC) maka usaha yang direncanakan layak secara finansial untuk dilaksanakan. Jika IRR lebih kecil dari SOCC maka usaha yang direncanakan tidak layak secara finansial.

Tabel 7. Analisis IRR Usaha Pengolahan Kerupuk Rambak di Desa Tugu Agung Kecamatan Lempuing Kabupaten OKI.

\begin{tabular}{|c|c|c|c|c|c|c|}
\hline \multirow{2}{*}{\multicolumn{2}{|c|}{$\frac{\text { Tahn Tahn Ka }}{2017}$}} & \multirow{2}{*}{$\begin{array}{l}\text { Pentapaten } \\
\text { (33.373.233) }\end{array}$} & \multirow{2}{*}{$\frac{C F 12 \%}{1.4049}$} & \multirow{2}{*}{$\begin{array}{c}\text { PV 12\% } \\
(46885990)\end{array}$} & \multicolumn{2}{|c|}{ CF $42 \%$ Prosent Vahe $42 \%$} \\
\hline & & & & & 286 & $(134250955)$ \\
\hline 2018 & 2 & 27.356517 & 1.2544 & 34316015 & 20 & 4812 \\
\hline 2019 & 1 & 33.708657 & 1.1200 & 37.753 .696 & 1.42 & 53.610248 \\
\hline 2020 & 0 & 11210714 & 10000 & 11210714 & 100 & 11210714 \\
\hline & & & OV & 36393435 & & -235.182 \\
\hline
\end{tabular}

Sumber : Data Olahan Primer, 2020.

$$
\begin{aligned}
& I R R=i+\frac{N P V+}{N P V+1)-(N P V-} \quad x(i z-i) \\
& I R R=12+\frac{36399.435}{36628616} \quad x(42-12) \\
& =12+\frac{36393435}{36628616} \quad x \text { (90) } \\
& =12+0.993579204 x \text { (6) } \\
& \begin{array}{l}
=12+29.80737882 \\
=41807
\end{array}
\end{aligned}
$$

Nilai NPV positif (+) adalah sebesar Rp 36.393.435 dan nilai NPV negatif (-) terkecil dengan nilai interest $\left(\mathrm{i}_{2}\right)$ sebesar $42 \%$ adalah sebesar $\mathrm{Rp}$ (235.182). Berdasarkan hasil perhitungan dengan menggunakan Compounding Faktor, maka diperoleh nilai IRR usaha pengolahan kerupuk rambak adalah sebesar 41,8 \% yang berarti nilai IRR lebih besar daripada nilai suku bunga bank atau SOCC (Social Opportunity Cost of Capital) sebesar $12 \%$. Hal ini menunjukan bahwa usaha pengolahan kerupuk rambak di Desa Tugu Agung Kecamatan Lempuing Kabupaten OKI layak secara financial untuk diteruskan.

\section{Analisis Net $\mathbf{B} / \mathbf{C}$}

Net Benefit Cost Ratio adalah penilaian yang dilakukan untuk melihat tingkat efisiensi penggunaan biaya berupa perbandingan jumlah nilai bersih sekarang yang positif dengan jumlah nilai bersih sekarang yang negative. Kriteria ini memberikan pedoman bahwa suatu proyek akan dipilih apabila nilai (Net $B / C>1$ ), sebaliknya bila suatu proyek memberikan nilai (Net $B / C<1$ ), maka proyek tidak diterima (diteruskan).

Tabel 8. Analisis Net B/C Usaha Pengolahan Kerupuk

Rambak di Desa Tugu Agung Kecamatan Lempuing Kabupaten OKI.

\begin{tabular}{ccccc}
\hline Tahun & Tahun Ke & Net Bensfit & CF $12 \%$ & Present Value 12\% \\
\hline 2017 & 3 & $(33.373 .233)$ & 1,4049 & $(46.886 .990)$ \\
2018 & 2 & 27.356 .517 & 1,2544 & 34.316 .015 \\
2019 & 1 & 33.708 .657 & 1,1200 & 37.753 .696 \\
2020 & 0 & 11.210 .714 & 1,0000 & 11.210 .714 \\
\hline
\end{tabular}

Sumber : Data Olahan Primer, 2020. 


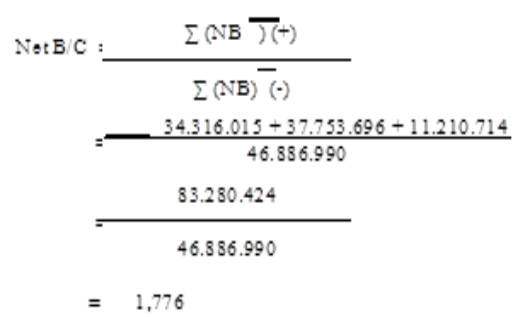

Nilai net $\mathrm{B} / \mathrm{C}$ diperoleh dengan menjumlahkan nilai Present Value Benefit (PVB) positif (+) kemudian hasilnya dibagi nilai PVB negatif (-). Berdasarkan hasil perhitungan pada tabel diatas diperoleh nilai PVB positif adalah sebesar Rp 83.280.424. Nilai PVB negatif adalah sebesar Rp 46.886.990 sehingga diperoleh nilai Net B/C adalah sebesar 1,77. Nilai net B/C 1,77 artinya bahwa setiap Rp 1 modal yang dikeluarkan untuk usaha pengolahan kerupuk rambak maka akan diperoleh keuntungan bersih setelah didiskonto (dikenai suku bunga bank) sebesar Rp 1,77. Nilai Net B/C > 1 berarti usaha pengolahan kerupuk rambak di Desa Tugu Agung Kecamatan Lempuing Kabupaten OKI layak secara financial untuk dikembangkan.

Tabel 9. Analisis Kelayakan Finansial Usaha Pengolahan Kerupuk Rambak di Desa Tugu Agung Kecamatan Lempuing Kabupaten OKI, Tahun 2017- 2020 pada Tingkat Suku Bunga 12\% (cf=12\%).

\begin{tabular}{clcr}
\hline No & Uraian & Satuan & \multicolumn{1}{c}{ Nilai } \\
\hline 1. & NPV & Rp & 36.393 .435 \\
2. & IRR & $\%$ & 41,8 \\
3. & Net B/C & & 1,77 \\
\hline
\end{tabular}

Sumber : Data Olahan Primer, 2020.

Berdasarkan perhitungan analisis NPV, IRR dan Net B/C di atas menunjukan bahwa usaha pengolahan kerupuk rambak di Desa Tugu Agung Kecamatan Lempuing Kabupaten OKI layak secara financial.

\section{V.KESIMPULAN DAN SARAN}

\section{A. Kesimpulan}

Berdasarkan hasil penelitian ini, maka kesimpulan yang dapat dimbil adalah sebagai berikut :

1. Biaya yang dikeluarkan untuk usaha pengolahan kerupuk rambak maka akan menghasilkan penerimaan sebesar Rp 1,09 atau dari setiap Rp 1 biaya yang dikeluarkan untuk usaha pengolahan kerupuk rambak maka akan diperoleh pendapatan sebesar Rp 0,09. Karena nilai $\mathrm{R} / \mathrm{C}>1$, ini menunjukkan bahwa usaha pengolahan kerupuk rambak di Desa Tugu Agung Kecamatan Lempuing Kabupaten OKI menguntungkan secara finansial.

2. Nilai tambah kerupuk rambak sebesar 5.750.000/Proses dikurangi dengan nilai biaya antara yaitu sebesar Rp 4.887.757/Proses sehingga diperoleh nilai tambah usaha pengolahan kerupuk rambak di Desa Tugu Agung Kecamatan Lempuing Kabupaten OKI adalah sebesar Rp 864.243/Proses produksi atau diperoleh nilai tambah per $\mathrm{Kg}$ penjualan kerupuk rambak adalah sebesar Rp 21.606. Hal ini menunjukan bahwa setiap penjualan $1 \mathrm{Kg}$ kerupuk rambak akan memberikan nilai tambah sebesar Rp 21.606. Hal ini menunjukan bahwa agroindustri pengolahan kerupuk rambak di Desa Tugu Agung Kecamatan Lempuing Kabupaten OKI dapat memberikan nilai tambah secara financial bagi pelaku usaha.

3. Berdasarkan hasil analisis NPV, IRR dan Net B/C bahwa usaha pengolahan kerupuk rambak di Desa Tugu Agung Kecamatan Lempuing Kabupaten OKI layak secara financial.

\section{B. Saran}

Adapun saran yang dapat direkomendasikan berdasarkan hasil penelitian yang telah dilakukan, usaha pengolahan kerupuk rambak di Desa Tugu Agung Kecamatan Lempuing Kabupaten OKI cukup menguntungkan maka usaha ini perlu dikembangkan dan dikelola lebih baik untuk dapat meningkatkan produksi.

\section{DAFTAR PUSTAKA}

Anonymous. 2011. Kerupuk. Wikipedia Bahasa Indonesia. http://id.wikipedia.org/wiki/Kerupuk. Diakses Mei 2020.

Ibrahim, Y. 2009. Studi Kelayakan Bisnis. Rineka Cipta. Jakarta.

Masyhuri, 2004. Pembangunan Agroindustri Melalui Peneliti Pengembangan Produk yang Intensif dan Berkesinambungan. Jurnal Jurusan Ekonomi Pertanian. Fakultas Pertanian UGM. Yogyakarta.

Nazir, M. 2005. Metode Penelitian. Ghalia Indonesia. Jakarta.

Rasyaf, M. 2008. Memasarkan Hasil Peternakan. Penebar Swadaya. Jakarta.

Soekartawi. 2002. Analisis Usahatani. Universitas Indonesia. Jakarta.

2003. Pengantar Agroindustri. Raja Grafindo Persada. Jakarta.

Soleh, M. 2003. Perbaikan Mutu dan Keamanan Pangan Produk Olahan Hasil Industri Kecil. Buletin Teknologi dan Informasi Pertanian Vol 6 Januari 2003. Departemen Pertanian Badan Penelitian dan Pengembangan Pertanian (BPTP). Jawa Timur.

Suratiyah, K. 2006. Ilmu Usahatani. Penebar Swadaya. Jakarta 